Jurnal Teknologi Informasi dan Komunikasi, ISSN: 2087-0868, Volume 11 Nomor 2, September 2020, Manajemen Pengelolaan Pemesanan dan Penjualan Produk Secara Online Menggunakan Metode Real Time Processing

\title{
Manajemen Pengelolaan Pemesanan dan Penjualan Produk Secara Online Menggunakan Metode Real Time Processing
}

\author{
Sri Handoko ${ }^{1}$, Hendri Rasminto ${ }^{2}$ \\ ${ }^{1,2}$ Program Studi Manajemen Informatika, Fakultas Ilmu Terapan, Universitas STEKOM, \\ Jl. Majapahit No 605, Kampus 1, Semarang, Indonesia 50275
}

\begin{abstract}
Abstrak
This study aims to design an ordering and sales information system at CV New Flashphone Semarang. Through the creation of the Ordering and Sales Information System, it is expected to be able to simplify the process of ordering and selling goods, as well as to make reports of goods more quickly, which is used by the company as a management tool in sales activities at CV New Flashphone Semarang.

The research method used is the Real Time Processing research method, which is one of the processing with concrete processes that uses online media. This input is done continuously and can automatically be obtained through the sensor. In using this real time processing, the user gets much more benefit because the time it takes to get the results is instant. So you don't have to wait long to get the desired result. The reaction is much faster than some of the previous processing.

The results of the research from the design of ordering and sales information systems are to make it easier for consumers to make purchases and order goods, as well as to facilitate companies in marketing their products and also make it easier for companies to control existing goods. Currently the company is still using a manual system in recording ordering transactions and selling goods, even though implementing an information system will minimize the risk of recording errors in reports, so that information is faster and more complete.
\end{abstract}

Keywords: Ordering and Sales Application, Real Time Processing,PHP,WEB

\begin{abstract}
Abstrak
Penelitian ini bertujuan untuk merancang sistem informasi pemesanan dan penjualan pada CV New Flashphone Semarang. Melalui pembuatan Sistem Informasi Pemesanan dan Penjualan ini diharapkan mampu untuk mempermudah dalam proses pemesanan dan penjualan barang, serta untuk membuat laporan barang secara lebih cepat, yang digunakan oleh perusahaan sebagai alat bantu pengelolaan dalam kegiatan penjualandi CV New Flashphone Semarang.

Metode penelitian yang digunakan adalah metode penelitian Real Time Processing adalah salah satu pengolahan dengan proses konret yang menggunakan media online. Input ini dilakukan secara terus menerus dan secara otomatis bisa didapat melalui sensor. Dalam menggunakan pengolahan real time ini si pengguna jauh lebih mendapatkan keuntungan banyak karena waktu yang dibutuhkan untuk memperoleh hasil sekejap saja. Jadi tidak perlu menunggu lama untuk mendapatkan hasil yang diinginkan. Reaksinya jauh lebih cepat dari beberapa pengolahan sebelumnya.

Hasil penelitian dari perancangan sistem informasi pemesanan dan penjualan adalah untuk memudahkan konsumen dalam melakukan pembelian dan pemesanan barang, serta untuk memudahkan perusahaan dalam memasarkan produknya dan juga memudahkan perushaan untuk melakukan pengontrolan barang yang ada. Saat ini perusahaan masih menggunakan sistem manual dalam pencatatan transaksi pemesanan maupun penjualan barang, padahal dengan menerapkan sistem informasi akan meminimalkan resiko dalam kesalahan pencatatan laporan, sehingga mendapatkan informasi yang lebih cepat dan lengkap.
\end{abstract}

Kata Kunci = Aplikasi Pemesanan Dan Penjualan, Real Time Processing, $P H P$, WEB

\section{Pendahuluan}

Perkembangan teknologi yang pesat dan memiliki potensi yang besar dalam perkembangan menejemen perusahaan, sehingga keberadaan komputer sangat penting dalam pengolahan data termasuk data penjualan. Baik usaha jasa maupun dagang dituntut untuk dapat menyesuaikan perkembangan teknologi tersebut guna menghasilkan informasi yang cepat, tepat dan akurat dan dapat bersaing dengan banyaknya kompetitor. Informasi yang akan dihasilkan nantinya akan sangat berguna dalam pengambilan 
keputusan selanjutnya. Penerapan sistem informasi dalam dunia usaha merupakan salah satu indikasi yang menandai kemajuan suatu usaha tersebut. Salah satunya dalam bidang penjualan berbagai jenis gadget, maupun accesories.

CV. New Flashphone Semarang adalah sebuah perusahaan yang bergerak dalam bidang distributor handphone, smartphone, accesories handphoneyang terletak pada jalan raya Pekunden Semarang. CV New Flashphone Semarang merupakan salah satu usaha milik perseorangan yang bergerak dalam bidang penjualan dan distributor berbagai macam produk gadget dan juga perlengkapan gadget. Beberapa costumer yang bermitra dengan CV. New Flashphone Semarang sejak tahun 2009 seperti counter handphone dan dan juga agen-agen handphone yang berada di kota Semarang, Magelang, Yogyakarta dan juga kota Solo.

CV. New Flashphone Semarang memiliki dua puluh lima karyawan yang mempunyai tugas dalam bagiannya masing-masing yaitu, lima karyawan bagian administrasi, sembilan karyawan bagian gudang, empat karyawan bagian penjualan, lima karyawan bagian kurir dan dua sebagai leader. Pada CV. New Flashphone ada beberapa posisi didalamnya, yaitu bagian penerimaan barang, bagian penerimaan hanya bertugas untuk menerima dan melakukan pengecekan awal pada barang yang diterima, yang kedua adalah bagian administrasi, tugas dari administrasi adalah melakukan input data kedalam komputer serta memberi label harga kedalam setiap barang yang datang, bagian selanjutnya adalah bagian admin gudang, bagian ini bertugas untuk melakukan pengecekan akhir pada barang yang datang, memberi kode pada barang dan juga membuat laporan akhir pada stok persediaan barang yang ada.

Pengelolaan penjualan yang ada saat ini pada CV. New Flashphone Semarang adalah pencatatanya masih menggunakan Microsoft Excel untuk Input data masuk dan data keluar dengan hal ini akan menambah lama waktu untuk mengerjakan laporan data karena dalam setiap memasukan data masuk maupun data keluar harus membuat form baru. Pengelolaan data penjualan dan penerimaan barang juga belum optimal karena belum adanyadatabase atau media penyimpanan data sehinggadistribusi data ke masing-masing bagian sering terjadi ketidak cocokan data antara bagian penerimaan, administrasi dan admin gudang. Perusahaan juga belum memiliki media pemasaran secara online jadi apabila costumer mau memesan ataupun membeli barang harus melalui sales yang berkunjung ke toko-toko, hal ini dikarenakan sales hanya berkunjung satu minggu sekali sehingga customer ketika ingin membeli harus datang langsung yang mengakibatkan waktu pemesanan kurang efisien [1]

Pengelolaan penjualan membutuhkan metode yang tepat, supaya sistem Informasi penjualan dapat menghadapi masalah yang ada pada objek penelitian. Metode realtime processing adalah transaksi individual yang dientri dengan melalui peralatan terminal, di-validasi dan digunakan untuk meng-update dengan segera file komputer, sebagai contoh penerimaan kas yang segera, secara langsung digunakan untuk meng-update akun costumer yang bersangkutan. Hasil pengolahan ini kemudian tersedia untuk permintaan keterangan atau laporan. [2]

Pemrosesan real time memberikan perusahaan keuntungan dalam menghadapi persaingan pada pasar, dengan memelihara informasi persediaan, staf penjualan dapat mengetahui dengan cepat bahwa terdapat persediaan di gudang. Sistem Penjualan berfungsi untuk mengelola semua data penjualan barang yang selalu mengalami perubahan yang meliputi jumlah dan nilai dari transaksi pembelian. Metode Realtime processing dilakukan dengan cara mencatat data pada saat transaksi berlangsung dan langsung diproses, sehingga dapat segera dihasilkan informasi. Pengolahan data model ini diperlukan untuk informasi yang harus bersifat up-to-date. [3]

Dari permasalahan yang ada penulis berkeinginan untuk membuat sistem pemesanan dan penjualan yang akan memberikan kemudahan bagi bagian penerimaan barang, administrasi dan admin gudang dalam mengelola data barang masuk maupun barang keluar karena di sistem yang baru akan dibangun dengan menggunakan metode real time processing, jadi apabila transaksi terjadi maka stok barang akan secara otomatis tercatat dalam laporan maka akan meminimalkan ketidak cocokan antara stok barang masuk dan barang keluar dan distribusi data ke bagian masing-masing tersebut lebih cepat, tepat dan efisien, dan

\section{Landasan Teori}

Pembuatan laporan yang masih membutuhkan waktu lama karena data harus dicatat kedalam buku laporan terlebih dahulu dan setelah itu baru di input kedalam Microsoft Excel sehingga membutuhkan waktu yang lama karena harus membuat form barang masuk dan form barang keluar.[4] 
Jurnal Teknologi Informasi dan Komunikasi, ISSN: 2087-0868, Volume 11 Nomor 2, September 2020, Manajemen Pengelolaan Pemesanan dan Penjualan Produk Secara Online Menggunakan Metode Real Time Processing

Perusahaan tidak mempunyai media pemasaran online karena sistem saat ini menggunakan interaksi langsung oleh sales kepada pelanggan sehingga menurunnya target penjualan setiap bulannya kurang meningkat dan menyebabkan perusahaan kalah bersaing dengan perusahaan lain yang bergerak dalam bidang serupa. Belum adanya pemrosesan penjualan yang cepat sehinga penyajian laporan penjualan dan laporan stok barang yang dihasilkan belum dapat diterima dalam waktu yang bersamaan.

\section{Metodologi}

Langkah-langkah penelitian

Langkah-langkah di atas dijelaskan sebagai berikut:

ini hanya menggunakan 6 tahapan sebagia beirkut:

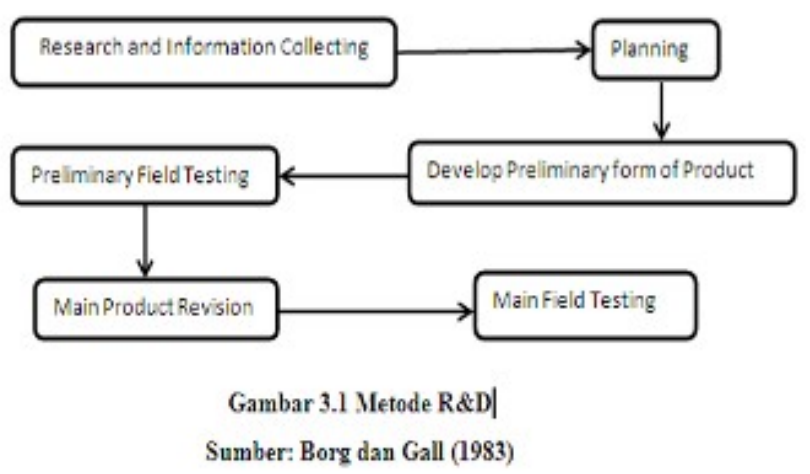

Gambar Metode pengembangan

Adapun secara spesifik beberapa langkah dijelaskan melalui berikut :

a. Tahap Research and Information Collecting

Pada tahap ini pengumpulan informasi dan penelitian melalui wawancara, observasi, dan studi pustaka terkait CV. New Flashphone Semarang. Wawancara dilakukan dengan bagian administrasi di CV. New Flashphone Semarang. Observasi atau pengamatan secara langsung terhadap sistem kerja yang sudah diterapkan. Terakhir studi pustaka sebagai sumber pendukung terhadap berbagai data yang sudah dikumpulkan.

$\Rightarrow$ Tahap Planning

Bagian dalam pembuatan perencanaan, meliputi menentukan tujuan, spesifikasi, atau karakteristik produk tertentu. Dilanjutkan dengan penggambaran flowchart, DFD, ERD, dan database.[5]

b. Tahap Develop Preliminary Form of Product

Pembuatan sistem perancangan yang dibantu dengan beberapa alar perancangan. Dalam tahapan ini terdapat beberapa bagian, seperti membuat sistem perancangan DFD, ERD, dan flowchart, serta program web

c. Tahap Preliminary Field Testing

Memberikan kepada para validator terkait pemberian berbagai saran atau masukan terkait kekurangan dan kelebihan produk. Pada tahapan ini validator memiliki hak untuk menentukan lulus atau tidaknya suatu produk.[6]

d. Tahap Main Prodcut Revision

Tahapan perbaikan dilaksanakan ketika ditemukannya berbagai kesalahan atau kelemahan dari hasil uji validasi. Dimana perbaikan ini memungkinkan dilakukan berkali-kali.

e. Tahap Main Field Testing

Tahapan ini sebagai penentu terkait uji validitas dengan mendapatkan pengesahan dari pihak yang berwenang. Setelah itu akan dilanjutkan dengan pembuatan program aplikasi.[7] 
4. Hasil dan Pembahasan

1. Form Beranda

Fungsi : Untuk menampilkan beberapa produk yang sedang dijual.

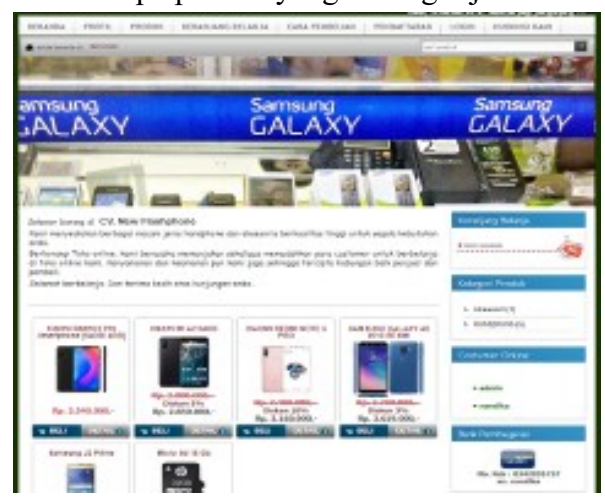

Gambar Form beranda

2. Form Pendaftaran

Fungsi : Digunakan untuk registrasi user baru.

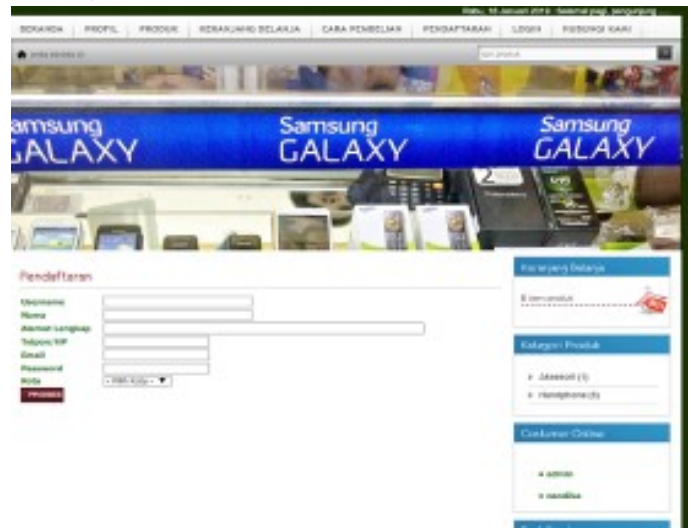

Gambar Form Pendaftaran

3. Form Log in

Fungsi : Digunakan untuk masuk ke web.

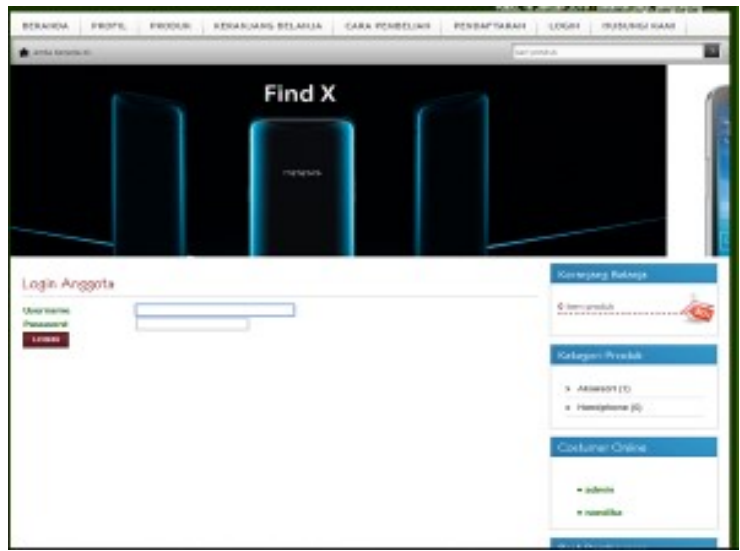

Gambar Form Log in 
Jurnal Teknologi Informasi dan Komunikasi, ISSN: 2087-0868, Volume 11 Nomor 2, September 2020, Manajemen Pengelolaan Pemesanan dan Penjualan Produk Secara Online Menggunakan Metode Real Time Processing

4. Form Keranjang Belanja

Fungsi : Untuk melihat hasil dari pembelian kita

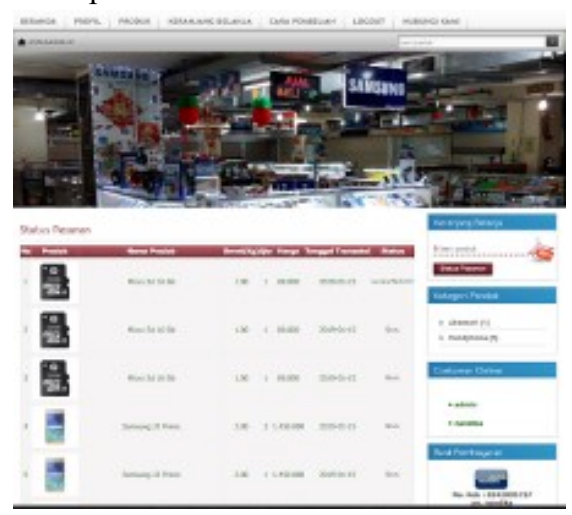

Gambar Form Keranjang Belanja

5. Form Detail Produk

Fungsi : Digunakan untuk menjelaskan detail produk yang dijual.

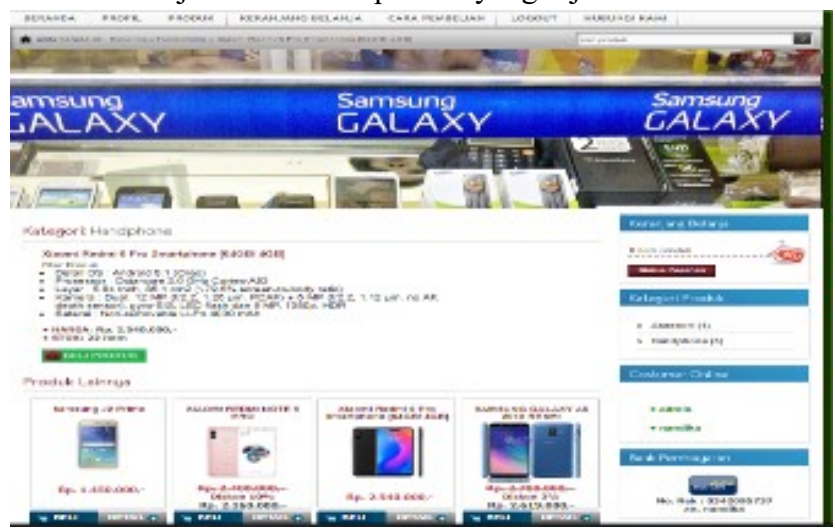

Gambar Form Detail Produk

6. Form Profil

Fungsi : Berisi tentang profil perusahaan

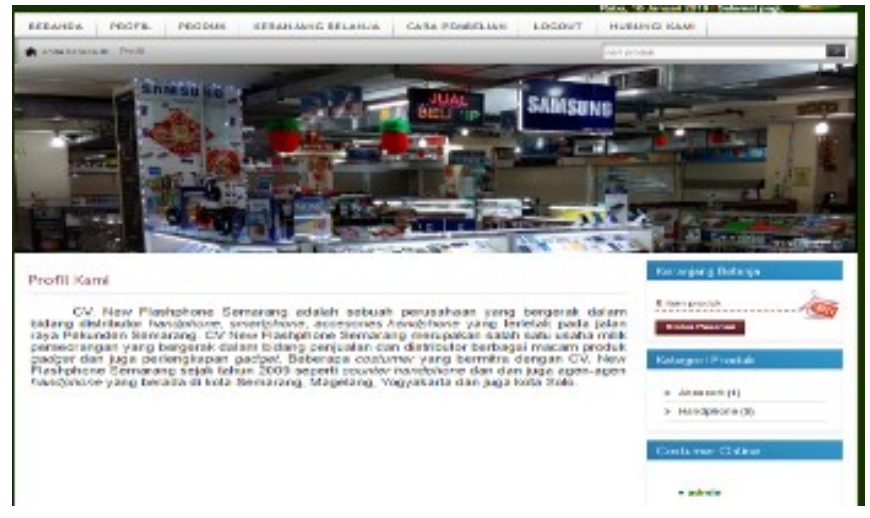

Gambar Profil 
7. Form Cara pembelian

Fungsi : Untuk melihat cara bagaimana melakukan pembelian.

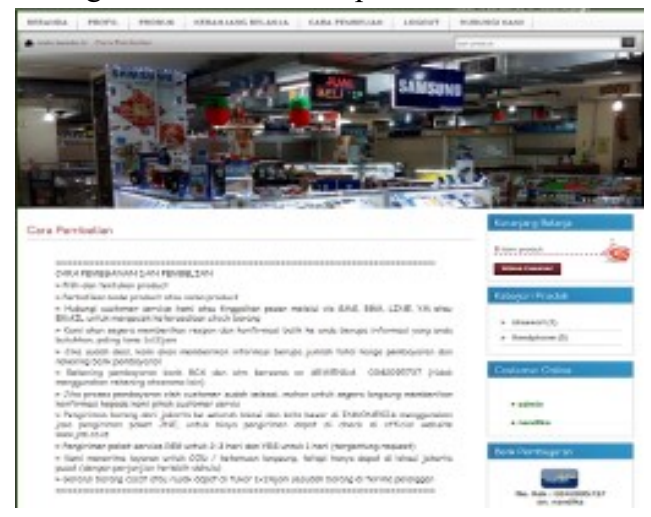

Gambar Form Cara Pembelian

8. Form Hubungi kami

Fungsi : Untuk user agar dapat berkomunikasi dengan costumer service.

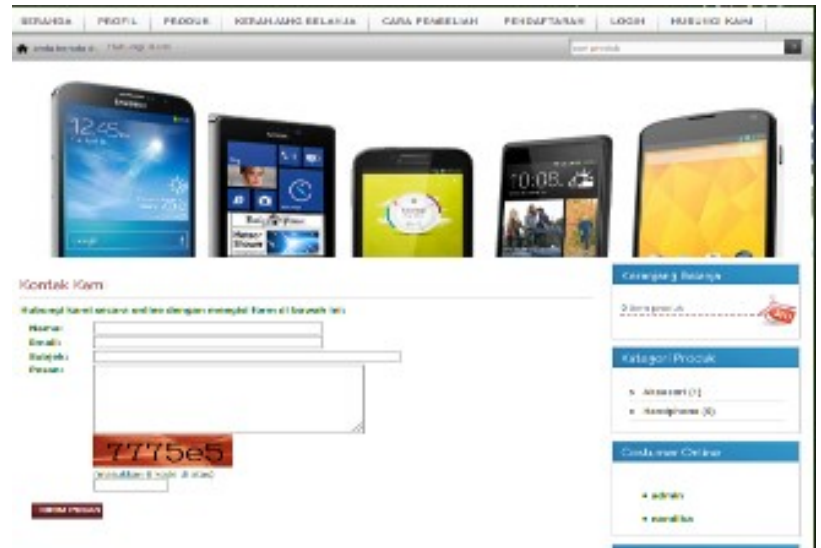

Gambar 15 Form Hubungi kami

9. Report Laporan Data Barang

Fungsi : Untuk Melihat data barang

\begin{tabular}{|c|c|c|c|c|c|c|}
\hline \multicolumn{7}{|c|}{$\begin{array}{l}\text { Laporan Baxang } \\
\text { Naw Wlanhphone Jemarang }\end{array}$} \\
\hline Mo & Mategori & $\operatorname{man}$ pxoduk & Maxga & Mexat: & Diskon & atak \\
\hline 1 & Akuensi & Micrs $9 d 16 \mathrm{~Gb}$ & D0.000,- & 1.00 & 0 & 2 \\
\hline 2 & handiphone & zansuza az pxtine & $1.450 .000,-$ & x.00 & a & $2 \times 5$ \\
\hline 3 & Hanciphone & 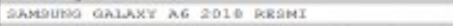 & $2.700 .000,-$ & 2.00 & 3 & 23 \\
\hline ? & 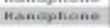 & 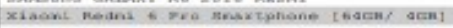 & $2,580,008,-$ & 2,00 & a & 22 \\
\hline 5 & Hancphone & XINONE RICHI ROTE 3 MPO & $2.400,000_{4}=$ & 2.00 & 10 & 34 \\
\hline . & Hamsiptiane & 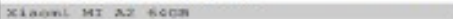 & 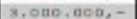 & 2.00 & $\mathrm{~s}$ & МT \\
\hline
\end{tabular}

Gambar Laporan Data Nasabah 
Jurnal Teknologi Informasi dan Komunikasi, ISSN: 2087-0868, Volume 11 Nomor 2, September 2020, Manajemen Pengelolaan Pemesanan dan Penjualan Produk Secara Online Menggunakan Metode Real Time Processing

10. Report Laporan Laporan Penjualan

Fungsi : Untuk menyajikan laporan Penjualan

Laporan Penjualan

CV New Flashphone Semarang

\begin{tabular}{|l|l|l|l|l|l|l|}
\hline No & Faktur & Tanggal & Nama Produk & Qty & Harga & Sub Total \\
\hline 1 & 60 & $24-12-2018$ & Micro Sd 16 Gb & 1 & $80.000,-$ & $80.000,-$ \\
2 & 66 & $15-01-2019$ & Micro Sd 16 Gb & 1 & $80.000,-$ & $80.000,-$ \\
\hline 3 & 60 & $24-12-2018$ & Samsung J2 Prime & 1 & $1.450 .000,-$ & $1.450 .000,-$ \\
4 & 64 & $24-12-2018$ & Samsung J2 Prime & 1 & $1.450 .000,-$ & $1.450 .000,-$ \\
5 & 65 & $08-01-2019$ & Samsung J2 Prime & 1 & $1.450 .000,-$ & $1.450 .000,-$ \\
\hline
\end{tabular}

Total keseluruhan: Rp. 4.510.000,-

Jumlah yang terjual : 5 unit

Jumlah keseluruhan yg terjual: 5 unit

Gambar Laporan Penjualan

\section{Kesimpulan}

Kesimpulan

Berdasarkan penelitian dan penyusunan skripsi dengan judul "Aplikasi Pemesanan dan Penjualan Menggunakan Metode Real Time Processingberbasis web pada CV. New Flashphone Semarang” dapat disimpulkan sebagai berikut:

1. Adanya media pemasaran online maka perusahaan dapat bersaing dengan perusahaan lain yang bergerak dalam bidang yang sama.

2. Sistem ini dapat memberikan kemudahan bagi pelanggan untuk melakukan pemesanan maupun pembelian barang dengan cepat tanpa harus menunggu sales datang terlebih dahulu.

3. Adanya media yang menyediakan informasi mengenai produk tersebut sehingga pemasaran yang dilakukan akan lebih maksimal

\section{Daftar Pustaka}

[1] Ali, Muhamad, 2013 ; "Perancangan Sistem Informsi untuk Pengendalian Stok secara Simultan dan Real Time Berbasis Mobile Agent pada Supply Chain”, Yogyakarta,Universitas Negeri Yogyakarta.

[2] Anivah, F, 2016; "Sistem Informasi Penjualan Menggunakan Metode Real Time Processing Berbasis Multiuser Pada CV. Tira Persada Jaya Semarang”, Skripsi, STEKOM, Semarang.

[3] Bonnie Soeherman, Marion Pinontoan, 2014;"'Designing Information System”, Jakarta, PT Gramedia

[4] Mulyadi, 2004;"Sistem Akuntansi. Edisi Kesembilan”, Yogyakarta: Sekolah Tinggi Hukum Ekonomi YKPN.

[5] Borg, W.R., dan Gall, M.D., 1983 ; "Educational research: An introduction (4ed)", New York, Longman.

[6] Nickels, William G., McHugh, James M., McHugh, Susan M. 1998 ; "Understanding Business 4th Edition",Amerika Serikat, McGraw Hill Comp. Inc.

[7] Noviyanto, Fiftin. 2011 ; "Penerapan Teknologi RIA untuk membangun Aplikasi Web dengan pengaksesan Real Time ISSN: 2528-6374”.Program Studi Teknik Informatika, Yogyakarta, UAD Yogyakarta. 